\title{
Taxonomy of the Neisseriae: Deoxyribonucleic Acid Base Composition, Interspecific Transformation, and Deoxyribonucleic Acid Hybridization
}

\author{
CAROLYN HOKE AND NEYLAN A. VEDROS \\ Naval Biosciences Laboratory, School of Public Health, University of California, Berkeley, California 94720
}

\begin{abstract}
Deoxyribonucleic acid (DNA) base composition, intergenic transformation efficiency, and DNA hybridization were used to determine the relatedness of a variety of established or proposed species of Neisseria and Branhamella. These studies indicated that these bacteria form three genetic groupings. Group I, comprised of $N$. meningitidis, $N$. gonorrhoeae, $N$. subflava, $N$. flava, $N$. perflava, $N$. sicca, $N$. mucosa, $N$. cinerea, $N$. flavescens, $N$. lactamica, $N$. elongata, $N$, canis, and $N$. denitrificans, was characterized by DNA base compositions ranging between 49.3 and $55.6 \mathrm{~mol} \%$ guanine plus cytosine. Group II, comprised of $N$. cuniculi, $N$. caviae, and $N$. ovis, was characterized by DNA base compositions ranging between 45.3 and 47.3 mol\% guanine plus cytosine. Group III, comprised of one species, B. catarrhalis, was characterized by DNA base compositions between 41 and 42 mol\% guanine plus cytosine. Transformation and DNA hybridization results revealed that members of each group, with few exceptions, exhibited high DNA homology with other members of the same group but most often distinctly lower levels of homology with members of a different group. These data suggest that $N$. ovis, $N$. caviae, and $N$. cuniculi may be significantly different from other neisseriae and from branhamellae to warrant their separation in a distinct genus.
\end{abstract}

The deoxyribonucleic acid (DNA) base compositions of several Neisseria and Branhamella species have been reported to range between 40 and $53 \mathrm{~mol} \%$ guanine plus cytosine $(\mathrm{G}+\mathrm{C})(5,6$, $8,18,19,26,30,31,34)$. Because different methods have been used, there have been variations in the $\mathrm{G}+\mathrm{C}$ values reported, and not all Neisseria species have been examined.

Transformation has played an important role in revealing taxonomic relationships of certain species of Haemophilus $(20,21)$, Streptococcus (28, 29), Bacillus (27), and Neisseria (8; B. W. Catlin, Bacteriol. Proc., p. 74, 1960, and p. 90, 1961). The studies on Neisseria supported the separation of $N$. catarrhalis into a new genus, Branhamella, and the incorporation of $N$. flava, $N$. perflava, and $N$. subflava into a single species ( $N$. subflava). The absence of transformation between selected Neisseria species and the positive transformation between asaccharolytic neisseriae and moraxellae have also supported changes in the family Neisseriaceae $(1,2)$.

The results of nucleic acid hybridizations performed by Kingsbury (17) revealed that the genus Neisseria was a heterogeneous group comprised of at least three distinct subgroups and questioned the proper classification of $N$. catarrhalis and $N$. caviae as members of the genus Neisseria. On the basis of nucleic acid hybridization studies, B $\phi v$ re reported that $N$. ovis, $N$. caviae, and B. catarrhalis showed distinct degrees of relatedness to several Moraxella species $(3,4)$. This supported the inclusion of Moraxella in the family Neisseriaceae.

The purpose of this study was to use DNA base composition determinations, transformation, and DNA hybridization studies to clarify the taxonomic positions of recognized or proposed species of Neisseria and Branhamella. Special attention was focused on evaluating the potential of transformation as a toxonomic tool for determining the relatedness of members of these genera.

\section{MATERIALS AND METHODS}

The bacterial strains examined are listed in Table 1. Stock cultures were preserved by freeze-drying. Working cultures were maintained at $-70^{\circ} \mathrm{C}$ in Trypticase soy broth (BBL Microbiology Systems) supplemented with $6 \%$ lactose. Cultures were routinely passaged on GC agar consisting of GC medium base (Difco Laboratories) and 1\% (vol/vol) chemically defined supplements (36) and were incubated at $36^{\circ} \mathrm{C}$ for $18 \mathrm{~h}\left(5 \% \mathrm{CO}_{2}\right.$, humidity).

Preparation of DNA for base composition determinations. A modification of the procedure originally described by Marmur (25) was followed for the extrac- 
TABLE 1. List of microorganisms used in this study

\begin{tabular}{|c|c|c|}
\hline $\begin{array}{l}\text { Laboratory } \\
\text { strain no. }\end{array}$ & Species & Source $^{a}$ \\
\hline M1803 & B. catarrhalis & ATCC $25238^{b}(1)$ \\
\hline M1835 & B. catarrhalis & Human nasopharynx (2) \\
\hline M637 & $N$. canis & $\operatorname{ATCC} 14678^{b}(1)$ \\
\hline M597 & N. caviae & $\operatorname{ATCC} 14659^{b}(1)$ \\
\hline M601 & N. cinerea & $\operatorname{ATCC} 14685^{b}(1)$ \\
\hline M635 & N. cuniculi & ATCC $14688^{b}$ \\
\hline CPH 21 & N. cuniculi & Alice Reyn (3) \\
\hline M598 & N. denitrificans & ATCC $14686^{b}(1)$ \\
\hline M1558 & N. elongata & $\operatorname{ATCC} 25295^{b}(1)$ \\
\hline M953 & N. flava & ATCC 14221 (1) \\
\hline F62 & N. gonorrhoeae & D. Kellogg (4) \\
\hline M1589 & N. gonorrhoeae & ATCC 27631 (1) \\
\hline M1802 & N. lactamica & $\operatorname{ATCC} 23970^{b}(1)$ \\
\hline M893 & N. lactamica & CDC A2894 (5) \\
\hline M1723 & N. lactamica & G. Taunay (6) \\
\hline Ne15 & N. meningitidis & B. W. Catlin (7) \\
\hline M628 & N. meningitidis & $\operatorname{ATCC} 13077^{b}(1)$ \\
\hline M630 & N. meningitidis & ATCC 13102 (1) \\
\hline M1801 & N. mucosa & ATCC $19696^{b}(1)$ \\
\hline M599 & N. mucosa & ATCC 19693 (1) \\
\hline CPH12 & N. mucosa & Alice Reyn (3) \\
\hline M1770 & N. ovis & ATCC 19575 (1) \\
\hline M1804 & $N$. perflava & $\operatorname{ATCC} 10555^{\circ}(1)$ \\
\hline Ne16 & N. perflava & B. W. Catlin (7) \\
\hline M1827 & N. perflava & Human nasopharynx (8) \\
\hline M472 & N. sicca & NRL 30016 (9) \\
\hline M600 & N. subflava & ATCC 19243 (1) \\
\hline
\end{tabular}

${ }^{a}$ (1) American Type Culture Collection, Rockville, Md. (2) Public Health Laboratory, San Francisco, Calif. (3) Ulrich Berger, Hygiene-Institut der Universität, Heidelberg, Germany. (4) Thomas Maier, Public Health Laboratory, San Luis Obispo, Calif. (5) Communicable Disease Centers, Atlanta, Ga. (6) G. Taunay, Sao Paulo, Brazil. (7) Medical College of Wisconsin, Milwaukee, Wis. (8) Our own laboratory. (9) Neisseria Reference Laboratory, U.S. Public Health Service Hospital, Seattle, Wash.

tion of DNA. In this modification, the DNA was extracted from cells grown in GC broth (prepared by using the formula of $\mathrm{GC}$ agar with the omission of starch and agar) or in a GC biphasic medium (1 part GC broth overlaid on 4 parts GC agar) and incubated at $36^{\circ} \mathrm{C}$ for $18 \mathrm{~h}$ (air) on a rotary shaker $(200 \mathrm{rpm}$; New Brunswick Scientific Co., New Brunswick, N.J.). The procedure was further modified to include additional ribonuclease and protease treatment of the crude DNA as follows. (i) Ribonucleic acid in the cell lysate, after treatment with lauryl sulfate, was digested at $37^{\circ} \mathrm{C}$ for $60 \mathrm{~min}$ by the addition of $50 \mu \mathrm{g}$ of ribonuclease (Sigma Chemical Co.) per $\mathrm{ml}$, which was preheated at $80^{\circ} \mathrm{C}$ for $10 \mathrm{~min}$ to destroy deoxyribonuclease, and (ii) excess protein in the cell lysate was digested at $37^{\circ} \mathrm{C}$ for 45 min by the addition of $2 \mathrm{mg}$ of protease (Sigma) per $\mathrm{ml}$. The crude DNA was then collected by precipitation with 2 volumes of chilled $100 \%$ ethanol. The DNA extraction then followed Marmur's procedure at the step in which the crude DNA is treated with sodium perchlorate. The purified DNA was stored in standard saline citrate (SSC: $0.15 \mathrm{M} \mathrm{NaCl}$ plus $0.015 \mathrm{M}$ trisodium citrate, $\mathrm{pH} 7.0$ ) at $4^{\circ} \mathrm{C}$ at a concentration between
0.5 and $1.5 \mathrm{mg}$ per $\mathrm{ml}$ in the presence of a few drops of chloroform. The DNA could be held in this manner for at least 6 months before performance of melting-point studies. Immediately before determinations of thermal melting point $\left(T_{m}\right)$, the DNA was reprecipitated in $100 \%$ ethanol, washed progressively in $70,80,90$, and $95 \%$ ethanol, and dissolved in $0.1 \times \mathrm{SSC}$.

Before the $T_{m}$ determinations were made, the purity of the DNA was checked on eight representative samples. The DNA concentration was determined by the diphenylamine reaction (7), with calf thymus DNA (Sigma) as a standard. Protein determinations on the DNA samples were performed by the method described by Lowry et al. (22). All samples contained less than $2 \%$ protein. To confirm purity, the hyperchromicities of all DNA samples were measured after thermal denaturation.

Determination of the DNA base composition. The $T_{m}$ determinations were made with a Beckman DU spectrophotometer equipped with a Gilford thermoprogrammer 2527 and thermal cuvettes. DNA was diluted to approximately $20 \mu \mathrm{g} / \mathrm{ml}$ in one lot of $0.1 \times$ SSC buffer. The temperature of the DNA was raised at a rate of $0.25^{\circ} \mathrm{C}$ per min, and the absorbance at $260 \mathrm{~nm}$ was recorded on a Moseley X-Y recorder (Hewlett Packard Co.). A buffer blank was run in parallel with each DNA sample to correct for optical density changes due to solvent expansion. The $T_{m}$ was determined as the temperature at the midpoint of the absorbance rise. The equation used to relate $T_{m}$ to moles percent $\mathrm{G}+\mathrm{C}$ was that used by Snell and Lapage (34):

$$
\begin{gathered}
\text { mol\% } \mathrm{G}+\mathrm{C}=\operatorname{mol} \% \mathrm{G}+\mathrm{C} \text { of reference strain }+ \\
\text { slope of equation } \times\left(T_{m} \text { of unknown }-T_{m}\right. \text { of } \\
\text { reference strain })
\end{gathered}
$$

For comparison, the $T_{m}$ determinations were adjusted to the equivalent values in SSC by means of the correction described by Mandel and Marmur (24), where $T_{m}(1 \times \mathrm{SSC})=T_{m}(0.1 \times \mathrm{SSC})+15.4^{\circ} \mathrm{C}$. The value 2.44 , determined both by Marmur and Doty (25) and by De Ley (9), was used for the slope of the equation. Escherichia coli B was chosen as the reference organism. The value 50.0 , previously derived by $T_{m}$ determination (26), was the value used for the moles percent $\mathrm{G}+\mathrm{C}$ of the reference strain. The value 91.3 was used as the $T_{m}$ of the reference strain and was derived by averaging $17 T_{m}$ determinations of $E$. coli $\mathrm{B}$ DNA (Sigma) under test conditions. Substituting these values in the equation gives:

$$
\mathrm{mol} \% \mathrm{G}+\mathrm{C}=50.0+2.44 \times\left(T_{m} \text { unknown }-91.3\right)
$$

The average $T_{m}$ from a minimum of three separate determinations was used as the $T_{m}$ of the unknown. To ensure repoducibility of results and to correct for minor differences in technique, chemical supplies, or other test conditions, the DNA from the reference strain, $E$. coli $\mathrm{B}$, was run in parallel with each sample. For the unknown $T_{m}$ to be considered valid, the $T_{m}$ of the reference DNA had to be in good correlation $( \pm 0.5 \%)$ with its predetermined value. To control for any significant variation in $T_{m}$ caused by the DNA extraction procedure, the DNA from $E$. coli ATCC 25922 was extracted in parallel with those of the test organisms, and its $T_{m}$ was compared with that of the commercially prepared $E$. coli B DNA (Sigma). The 
$T_{m}$ for the DNA extracted from $E$. coli ATCC 25922 was $91.3^{\circ} \mathrm{C}$ and was identical to that determined for the DNA of $E$. coli B (Sigma).

Selection of streptomycin-resistant mutants. A heavy suspension of organisms containing approximately $10^{9}$ colony-forming units per ml was swabbed liberally in a confluent manner on GC agar containing $1,000 \mu \mathrm{g}$ of streptomycin (streptomycin sulfate, USP, Eli Lilly Co.) per $\mathrm{ml}$. The plates were incubated for $75 \mathrm{~h}\left(36^{\circ} \mathrm{C}\right.$, $5 \% \mathrm{CO}_{2}$ ). Isolated colonies were picked and subcultured three times on plain GC agar and GC agar containing $1,000 \mu \mathrm{g}$ of streptomycin per $\mathrm{ml}$ to confirm that a stable streptomycin-resistant, nondependent mutant had been selected.

Preparation of DNA for transformation experiments. DNA was prepared from the streptomycin-resistant organisms by the technique described by Maier, Zubrzycki, and Coyle (23). The procedure was modified slightly to include a 15-min incubation of the cell lysate with ribonuclease A (Sigma), $50 \mu \mathrm{g} / \mathrm{ml}\left(37^{\circ} \mathrm{C}\right.$, water bath), prior to its treatment with protease (Sigma). The final concentration of DNA was quantitated by the diphenylamine reaction (7).

Standard transformation procedure. Transformation procedures were performed in a manner slightly modified from that described by Maier, Zubrzycki, and Coyle (23). Eighteen-hour-old cultures of the recipient organisms were suspended at a concentration of approximately $3 \times 10^{8}$ colony-forming units per $\mathrm{ml}$ in GC broth containing $2 \mathrm{mM} \mathrm{MgCl}_{2}$ and were exposed to the action of a Vortex mixer to minimize cell clumping. Virulent-type colonies were selected for studies evaluating $N$. gonorrhoeae as a recipient organism. To a tube containing $1.8 \mathrm{ml}$ of the organism suspension was added $0.2 \mathrm{ml}$ of DNA solution to make a final concentration of 1 to $2 \mu \mathrm{g} / \mathrm{ml}$. This concentration of DNA was considered to be optimal on the basis of DNA dilution experiments performed on representative organisms. The mixture was incubated in a water bath at $37^{\circ} \mathrm{C}$ for $30 \mathrm{~min}$. Deoxyribonuclease (Sigma) was added to the mixture at a final concentration of $25 \mu \mathrm{g} / \mathrm{ml}$ (to destroy unbound DNA), and after $2 \mathrm{~min}$ the mixture was serially diluted in GC broth. Portions $(0.1 \mathrm{ml})$ of the appropriate dilution were spread onto each of three plates containing $20 \mathrm{ml}$ of antibiotic-free $\mathrm{GC}$ agar. As controls for each experiment, a suspension of cells not treated with DNA was plated from the same dilutions to determine the number of spontaneous streptomycin-resistant mutant colony-forming units. The plates were incubated for 5 to $6 \mathrm{~h}\left(36^{\circ} \mathrm{C}, \mathrm{CO}_{2}\right)$ to allow phenotypic expression of antibiotic resistance. The agar containing the microcolonies was layered on top of $20 \mathrm{ml}$ of GC agar containing 1,000 $\mu \mathrm{g}$ of streptomycin per $\mathrm{ml}$. The double-layered agar plates were incubated for $72 \mathrm{~h}\left(36^{\circ} \mathrm{C}, 5 \% \mathrm{CO}_{2}\right)$. At this time, the streptomycin-resistant transformants were counted, and the average count of the three plates was used for determination of all colony counts. The number of colony-forming units exposed to DNA was determined from plate counts of the same dilutions of cell suspension that were plated on plain GC agar only.

DNA hybridization. The extraction of DNA was similar to the procedures described above except that Trypticase soy broth was used instead of GC broth to grow all organisms except $N$. gonorrhoeae. The extracted DNA was diluted to an optical density of 2.0 $(260 \mathrm{~nm}$ ) in $0.1 \times$ SSC (approximately $100 \mu \mathrm{g} / \mathrm{ml}$ ) and was sheared at $21,000 \mathrm{lb} / \mathrm{in}^{2}$ in a Ribi cell fractionator (model RF-1; Ivan Sorvall, Inc., Norwalk, Conn.). This automated, temperature-controlled French pressure cell was the most effective of several procedures tried in producing homogeneous DNA fragments. Homogeneity was determined by analytical zone centrifugation (the majority of DNA fragments were approximately 400,000 daltons).

Renaturation rates were determined for hybridization by the technique of De Ley et al. (10). The optimal renaturation rate temperature was based on the base composition of each isolate and was calculated by the formula of De Ley (11). The average was $74^{\circ} \mathrm{C}$, and this temperature was used in all experiments. Renaturation rates were recorded for $30 \mathrm{~min}$ on a Gilford spectrophotometer (model 252) with thermal programmer (model 2527; Gilford Instruments, Oberlin, Ohio). The blank in the thermal cuvettes consisted of a guanine solution (optical density, $2.0 ; 260 \mathrm{~nm}$ ), and the instrument was set at a dwell time of $4 \mathrm{~s}$ with a chart speed of $0.5 \mathrm{~cm} / \mathrm{min}$.

\section{RESULTS}

DNA base composition. The DNA base compositions of the 16 established or proposed species of Neisseria and Branhamella included in this study are listed in Table 2 and are compared with the values previously reported for the same species. As depicted in Fig. 1, the $G+C$ values appear to cluster in three distinct groups. The majority of the species examined, including $N$. meningitidis, $N$. gonorrhoeae, $N$. subflava, $N$. flava, $N$. perflava, $N$. sicca, $N$. mucosa, $N$. cinerea, $N$. flavescens, $N$. lactamica, $N$. elongata, $N$. canis, and $N$. denitrificans, was characterized by $\mathrm{G}+\mathrm{C}$ values of 49.3 to $55.6 \mathrm{~mol} \%$. Two strains of $B$. catarrhalis formed a second group characterized by distinctively lower values of 41 to $42 \mathrm{~mol} \% \mathrm{G}+\mathrm{C}$. The DNA base compositions of $N$. cuniculi, $N$. ovis, and $N$. caviae fell intermediate between those of the latter two groups, with values between 45.3 and $47.3 \mathrm{~mol} \%$.

Transformation. Preliminary screening of several reference strains of Neisseria and Branhamella revealed considerable variation in their competence for transformation. For purposes of this study, it was necessary to select recipient cells with high-level competence (homologous transformation efficiencies greater than $0.5 \%$ ) to ensure that differences between the transformation frequency and the spontaneous mutation rate to streptomycin resistance would be great enough to reveal gradations of transformation frequencies based on the homology of heterologous DNA. As a result, five reference strains of Neisseria and Branhamella species were selected to serve as recipients for the donor DNAs from nine other reference Neisseria and Branhamella species. The results of these studies are summarized in Table 3 . Significant levels of transformation between all species of Neisseria 


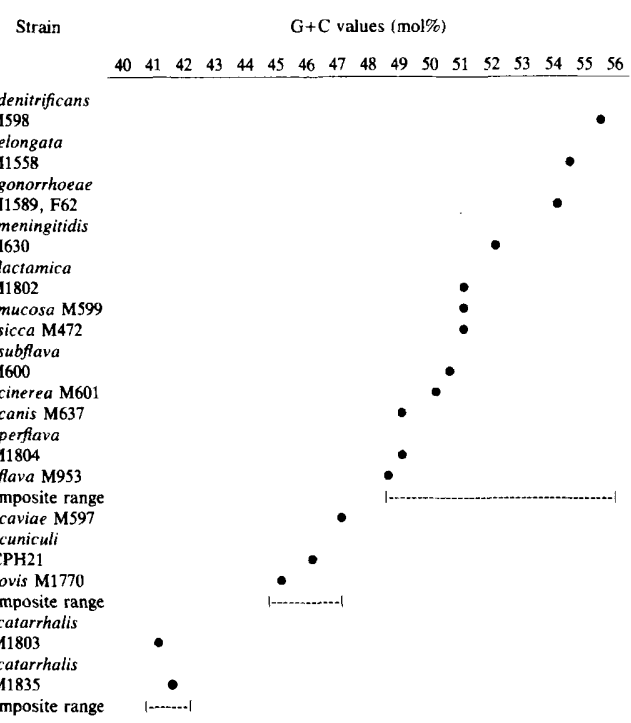

FIG. 1. Principal groupings of reference strains of Neisseria and Branhamella species according to DNA base ratios. Each dot represents the moles percent $\mathrm{G}+\mathrm{C}$ calculated from the average of a minimum of three $T_{m}$ determinations.

examined were revealed. Both $N$. meningitidis and $N$. gonorrhoeae were transformed by each other's DNA at significantly higher frequencies than any other donor DNA, indicating a close genetic relationship. $N$. gonorrhoeae and $N$. meningitidis were transformed by the DNA of $N$. sicca, $N$. flava, $N$. perflava, and $N$. subflava at intermediate frequencies. DNA from N. lactamica transformed $N$. perflava at high frequencies and $N$. gonorrhoeae and $N$. meningitidis at intermediate to high levels, although $N$. lactamica, as a recipient, was not transformed by any heterologous DNA at significant levels. It is of interest to note that $N$. perflava accepted DNA from $N$. sicca at slightly higher frequencies than it accepted DNA from $N$. flava and $N$. subflava, since the latter two organisms, along with $N$. perflava, have been proposed to be included in a single species, $N$. subflava, without the inclusion of $N$. sicca. DNA from $N$. mucosa transformed several Neisseria species at intermediate frequencies. In contrast to the transformation occurring between members of the genus Neisseria, $B$. catarrhalis was not transformed by any heterologous DNA at a significant level and could not serve as a donor to transform any recipient cells of Neisseria species at a significant level. It has been shown that $N$. caviae and $N$. ovis contain dehydrogenase systems similar to that of $B$. catarrhalis $(14,15)$. Our transformation studies, however, revealed that DNA from $N$. caviae, $N$. ovis, and $N$. cuniculi transformed $B$. catarrhalis at very low levels and did not indicate a close genetic relatedness (Table 4).

DNA hybridization. Table 5 lists the results of DNA hybridization studies between selected species of Neisseria and Branhamella and confirms the close genetic relatedness occurring

TABLE 2. DNA base compositions of Neisseria and Branhamella species

\begin{tabular}{|c|c|c|c|c|c|c|}
\hline \multirow[b]{2}{*}{ Test organism } & \multicolumn{3}{|c|}{ Present study } & \multicolumn{3}{|c|}{ Previous reports } \\
\hline & Strain $^{a}$ & $T_{m}$ (avg) & $\begin{array}{c}\mathrm{G}+\mathrm{C} \\
(\mathrm{mol} \%)\end{array}$ & $T_{m}$ & Buoyant density & Chromatography \\
\hline N. denitrificans & M598 & $93.58( \pm 0.16)^{b}$ & 55.6 & & & \\
\hline N. elongata & M1558 & $93.21( \pm 0.32)$ & 54.7 & & $53.0[6]^{c}$ & \\
\hline \multirow[t]{2}{*}{ N. gonorrhoeae } & F62 & $92.64( \pm 0.09)$ & 53.3 & & & $49.6[18]$ \\
\hline & M1589 & $92.67( \pm 0.17)$ & 53.3 & & & \\
\hline$N$. meningitidis & M630 & $92.1 \quad( \pm 0.27)$ & 52.0 & $51.5[25]$ & $50.0[30]$ & $50.5-51.3[8,18]$ \\
\hline N. lactamica & M1802 & $91.98( \pm 0.24)$ & 51.7 & & & \\
\hline N. mucosa & M599 & $91.96( \pm 0.28)$ & 51.6 & & $50.5-52.0[29]$ & \\
\hline$N$. sicca & M472 & $91.78( \pm 0.19)$ & 51.2 & $49.0[25]$ & $51.0[30]$ & $51.5[8]$ \\
\hline N. subflava & M600 & $91.7( \pm 0.2)$ & 51.0 & & & $50.5[8]$ \\
\hline$N$. cinerea & M601 & $91.66( \pm 0.18)$ & 50.9 & & $49.0[5]$ & \\
\hline N. canis & M637 & $91.15( \pm 0.3)$ & 49.6 & & & \\
\hline N. perflava & M1804 & $91.14( \pm 0.19)$ & 49.6 & $49.0[25]$ & $48.0[30]$ & $49.2-50.5[8,17]$ \\
\hline N. flava & M953 & $91.0 \quad( \pm 0.06)$ & 49.3 & & & $49.5[8]$ \\
\hline N. flavescens & & & & $49.0[25]$ & $46.5-47.5[5,30]$ & $50.1[8]$ \\
\hline N. caviae & M597 & $90.21( \pm 0.17)$ & 47.3 & $46.6-47.3[33]$ & $44.5[5]$ & $47.3-50.4[17]$ \\
\hline N. cuniculi & CPH21 & $90.0 \quad( \pm 0.11)$ & 46.8 & $44.6[33]$ & & \\
\hline N. ovis & M1770 & $89.36( \pm 0.13)$ & 45.3 & $46.0-46.3[33]$ & $44.5-45.0[5]$ & \\
\hline \multirow[t]{2}{*}{ B. catarrhalis } & M1803 & $87.73( \pm 0.12)$ & 41.3 & $41.0-41.9[25,33]$ & $41.0-42.5[5,30]$ & $40.1-45.7[8,18]$ \\
\hline & M1835 & $87.85( \pm 0.09)$ & 41.6 & & & \\
\hline
\end{tabular}

\footnotetext{
${ }^{a}$ Strains used in this study only.

${ }^{b}$ Numbers in parentheses represent standard deviations.

${ }^{c}$ Numbers in brackets refer to references.
} 


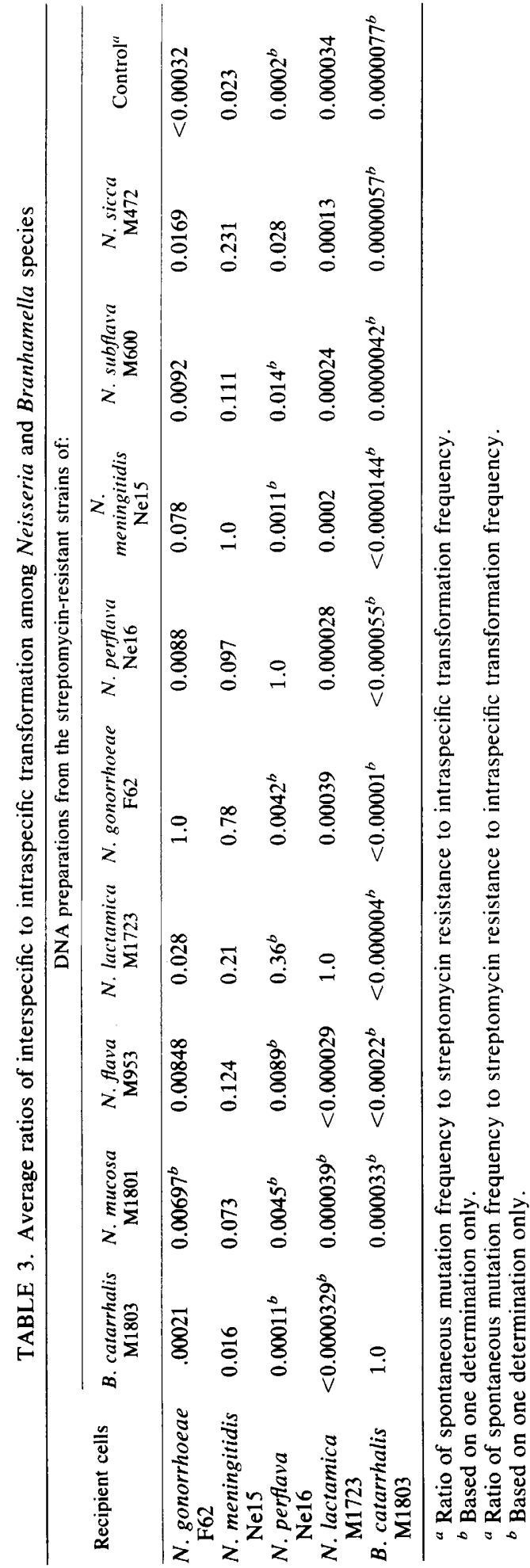

between those species of Neisseria characterized by DNA base compositions between 49.3 and $55.6 \mathrm{~mol} \% \mathrm{G}+\mathrm{C}$ (Fig. 1). With the exception of $N$. denitrificans and $N$. canis, all members of this group demonstrated at least $60 \%$ DNA binding with one another. The slightly lower DNA homologies of $N$. canis and $N$. denitrificans with the other members of this group suggest that species of animal origin other than humans are more distantly related to the human isolates. Further studies on additional strains of $N$. canis and $N$. denitrificans would be desirable before any further recommendations on their taxonomic status are made. As indicated in the transformation studies (Table 3), the hybridization data revealed a high level of homology between $N$. meningitidis and $N$. gonorrhoeae DNA (93.17\% binding), and $N$. lactamica DNA demonstrated the highest degrees of binding with $N$. meningitidis, $N$. gonorrhoeae, and $N$. perflava DNA $(79,80$, and $75 \%$ binding, respectively). Among those tested, N. mucosa DNA demonstrated the highest degree of homology with $N$. perflava DNA ( 77 to $91 \%$ binding). A high level of homology among $N$. perflava, $N$. sicca, and $N$. flava DNA was revealed in this study. As summarized in Table 6, the incorporation of $N$. perflava, $N$. subflava, and $N$. flava into a single species ( $N$. subflava) without the inclusion of $N$. sicca is not supported by these data. These data, in fact, suggest that $N$. perflava, N. sicca, and $N$. flava are more closely related to one another than they are to $N$. subflava. Although the data revealed a high degree of relatedness between $N$. mucosa and $N$. perflava DNAs, $N$. mucosa DNA did not appear to have high enough homology with $N$. subflava, $N$. flava, or $N$. sicca DNA to be considered part of a single species.

DNAs from organisms (N. mucosa, N. denitrificans, and $N$. canis) representing the group of neisseriae with DNA base compositions of 49.3 and $55.6 \mathrm{~mol} \% \mathrm{G}+\mathrm{C}$ demonstrated only low levels of homology with $B$. catarrhalis (16 to $35 \%$ binding). These data and the transformation data support the placement of $B$. catarrhalis in a separate genus.

DNAs from organisms ( $N$. ovis and $N$. cuniculi) representing that group of gram-negative cocci with DNA base compositions of 45.3 to $47.3 \mathrm{~mol} \% \mathrm{G}+\mathrm{C}$ demonstrated low degrees of homology with the DNAs of selected neisseriae representing the range of 49.3 to $55.6 \mathrm{~mol} \%$ $\mathrm{G}+\mathrm{C}(23$ to $42 \%$ binding) and with $B$. catarrhalis (32 to $38 \%$ binding). $N$. ovis and $N$. cuniculi demonstrated significantly greater homology with each other ( $57.8 \%$ binding). These data and the transformation data (Table 4) suggest that $N$. ovis, $N$. cuniculi, and $N$. caviae represent a third genetic group, distinct from the other gram- 
TABLE 4. Ratios of average interspecific to intraspecific transformation among Branhamella and Neisseria species

\begin{tabular}{lccccc}
\hline Recipient cells & \multicolumn{4}{c}{ DNA preparations from streptomycin-resistant strains of: } \\
\cline { 2 - 6 } & $\begin{array}{c}\text { B. catarrhalis } \\
\text { M1803 }\end{array}$ & $\begin{array}{c}\text { N. caviae } \\
\text { M597 }\end{array}$ & $\begin{array}{c}\text { N. ovis } \\
\text { M1770 }\end{array}$ & $\begin{array}{c}\text { N. cumiculi } \\
\text { M635 }\end{array}$ & Control $^{a}$ \\
\hline B. catarrhalis & 1 & $<0.000033$ & 0.000032 & 0.000026 & 0.000013
\end{tabular}

M1803

${ }^{a}$ Ratio of spontaneous mutation frequency to streptomycin resistance to intraspecific transformation frequency.

negative cocci, with genetic affinities intermediate between the neisseriae and the branhamellae.

\section{DISCUSSION}

Although much uncertainty exists over comparisons of moles percent $\mathrm{G}+\mathrm{C}$ determined in different laboratories where different strains and materials have been used, this study found the precision of $T_{m}$ determinations performed within this laboratory to be high. Of a minimum of three individual $T_{m}$ values determined on each organism in this study, the standard deviation was less than $\pm 0.4^{\circ} \mathrm{C}$ (equivalent to less than \pm 1 mol\% $\mathrm{G}+\mathrm{C}$ ) on each DNA sample. The $\mathrm{G}+\mathrm{C}$ values determined in this study correlate well ( $<2.2 \%$ difference) with those previously reported (Table 2), with the exception of those determined for two strains of $N$. gonorrhoeae. Minor differences $(<2.2 \%)$ in reported $\mathrm{G}+\mathrm{C}$ content could be due to differences in strains, methods, or reagents, or, in the case of $T_{m}$ determinations, variations in temperature calibrations. In an attempt to minimize any variations caused by these factors, each $\mathrm{G}+\mathrm{C}$ value was calculated with respect to an internal standard of $E$. coli $\mathrm{B}$ DNA (Sigma), which had a $\mathrm{G}+\mathrm{C}$ value $(50.0$ mol\%) in the range of the organisms investigated in this study. The reason for the large difference between the $\mathrm{G}+\mathrm{C}$ value reported for $N$. gonorrhoeae by Lee et al. (19) and the values obtained for that organism in this study is unclear. The $\mathrm{G}+\mathrm{C}$ value reported in their study and based on a chromatographic analysis of one strain was $49.6 \mathrm{~mol} \%$, whereas the values determined in this study for $N$. gonorrhoeae (strains M 1589 and F 62) were $53.3 \mathrm{~mol} \%$. If real, a $3.7 \mathrm{~mol} \%$ $\mathrm{G}+\mathrm{C}$ difference between these strains would indicate considerable heterogeneity within this species, which has not previously been suggested. The values listed under $N$. gonorrhoeae (F 62) in Table 2 represent the composite of two individual DNA extractions of this organism. All results demonstrated close agreement with each other. Unless additional strains of $N$. gonorrhoeae indicate differently, our study suggests that the $\mathrm{G}+\mathrm{C}$ content of $N$. gonorrhoeae is higher than that previously accepted.
Preliminary screening for competent recipients for transformation studies revealed considerable variation in the levels of competence demonstrated by different species of gram-negative cocci and by different strains of a single species. In several instances, low-level competence did not appear to be related to the number of laboratory passages from the source. Varying the type and concentration of cations, in several cases, did not significantly increase the efficiency of transformation among strains demonstrating low-level competence. In addition to the variation in competence levels demonstrated by different strains, some organisms appeared to be stable in their high transformation efficiency whereas others varied from high to low levels of competence, even when experimental conditions were duplicated as closely as possible. It has previously been reported that some competent strains of $N$. meningitidis yield a proportion of incompetent variants that exhibit either decreased transformibility or a complete and permanent loss of competence (16). Competence in transformation has been correlated with pili in some species of Neisseria and Moraxella (12, $13,35)$. Transformation studies with $N$. gonorrhoeae revealed that the nonpiliated $\mathrm{T} 3$ and $\mathrm{T} 4$ colonies, which emerge upon nonselective subculture of $\mathrm{T} 1$ and $\mathrm{T} 2$ colonies, have at least 1,000-fold lower competence levels than are obtained with the piliated $\mathrm{T} 1$ and $\mathrm{T} 2$ colonies (35). Thus, in the case of $N$. gonorrhoeae, by relating competence to a colonial marker, one can easily select colonies that are consistently competent for transformation. The same situation could exist with other Neisseria species, except that no colonial marker for competence has been identified. As a result, arbitrary selection of colonies to serve as recipients in transformation studies may result in a mixture of competent cells and incompetent cells that could cause apparent variations in competence. Additional studies addressing the factors affecting competence in other Neisseria species would be valuable for elucidating these problems and would enable transformation to be a more easily utilized tool for determining relationships.

In the past, most investigators have chosen 


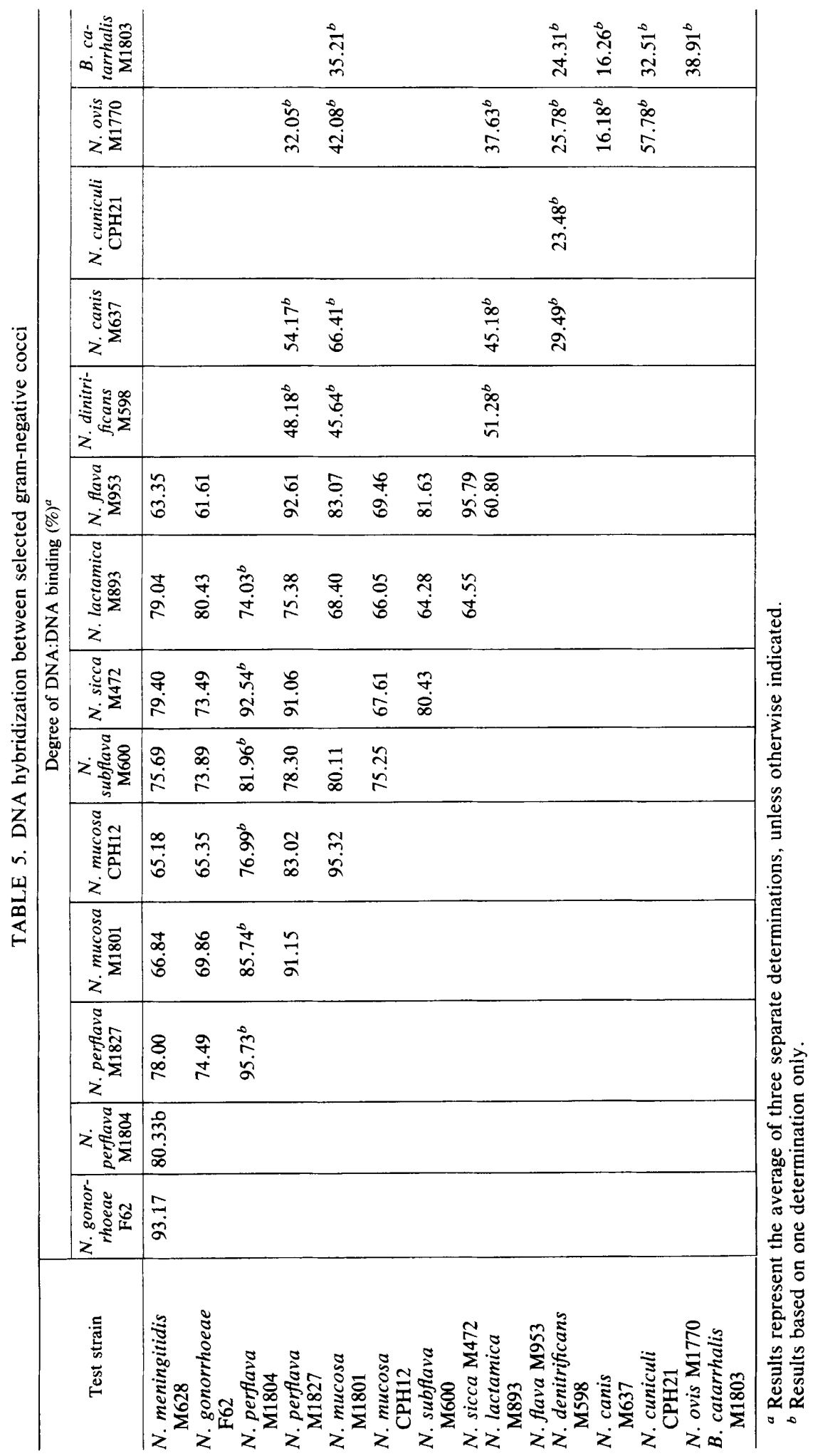


TABLE 6. DNA hybridization between Neisseria species proposed to be incorporated as a single species ${ }^{a}$

\begin{tabular}{lccccc}
\hline \multirow{2}{*}{ Test strain } & \multicolumn{4}{c}{ Degree of DNA:DNA binding (\%) } \\
\cline { 2 - 5 } & $\begin{array}{c}\text { N. perflava } \\
\text { M1804 }\end{array}$ & $\begin{array}{c}\text { N. perflava } \\
\text { M1827 }\end{array}$ & $\begin{array}{c}\text { N. subflava } \\
\text { M600 }\end{array}$ & $\begin{array}{c}\text { N. sicca } \\
\text { M472 }\end{array}$ & $\begin{array}{c}\text { N. flava } \\
\text { M953 }\end{array}$ \\
\hline N. perflava M1804 & & $95.73^{c}$ & $81.96^{c}$ & $92.54^{c}$ & \\
N. perflava M1827 & & 78.30 & 91.06 & 92.61 \\
N. subflava M600 & & & 80.43 & 81.63 \\
N. sicca M472 & & & & 95.79 \\
N. flava M953 & & & & \\
\hline
\end{tabular}

${ }^{a}$ Reference 8 .

${ }^{b}$ Results represent the average of three separate determinations unless otherwise indicated.

${ }^{c}$ Results based on one determination only.

high-level resistance to streptomycin as the chromosomal marker for studying transformation between members of the family Neisseriaceae. The relative conservation in nature of genes coding for ribosomal components and the observation that the integration and expression barriers are less likely to operate with ribosomal markers than with other markers have been previously discussed (2). Siddiqui and Goldberg (32) reported that the use of several markers in transformation experiments has increased information concerning the genetic relatedness of selected species of Neisseria. $N$. gonorrhoeae was observed to exhibit marker selectivity in its ability to be transformed by heterologous DNA and was often transformed by the gene for streptomycin resistance at higher frequencies than with nutritional markers. This observation suggests that the potential for use of transformation as a guide to genetic relatedness may be enhanced by the use of several chromosomal markers.

Despite the problems encountered in finding suitable recipient cells, the results of this study indicate that transformation can serve as a valuable taxonomic tool. The genetic relationships revealed in this transformation study were supported by the DNA hybridization results of this study and others (17). Because transformation, unlike DNA hybridization, is influenced not only by the homology of the DNA but also by the internal biological environment of the cell (including integration and restriction enzymes), absolute correlations between the techniques cannot be made. For instance, some recipient organisms in transformation appear much more

TABLE 7. Genetic groupings of Neisseria and Branhamella species based on DNA base composition, transformation, and DNA hybridization studies

\begin{tabular}{|c|c|c|c|c|c|c|c|c|}
\hline \multirow[t]{2}{*}{ Group } & \multirow{2}{*}{ Microorganism } & \multirow{2}{*}{$\begin{array}{c}\text { DNA base } \\
\text { composition range } \\
(\mathrm{mol} \%)\end{array}$} & \multicolumn{3}{|c|}{$\begin{array}{l}\text { Transformation with members of } \\
\text { group }\end{array}$} & \multicolumn{3}{|c|}{$\begin{array}{l}\text { DNA hybridization with } \\
\text { members of group }\end{array}$} \\
\hline & & & I & II & III & I & II & III \\
\hline I & $\begin{array}{l}\text { N. gonorrhoeae } \\
N . \text { meningitidis } \\
N . \text { subflava } \\
N . \text { flava } \\
N . \text { perlava } \\
N . \text { sicca } \\
N . \text { mucosa } \\
N . \text { cinerea }^{c} \\
N . \text { flavescens }^{c} \\
N . \text { elongata }^{c} \\
\text { N. lactamica }\end{array}$ & $49.3-54.7$ & High & TND & Very low & $\geq 62^{b}$ & $\geq 42$ & $\leq 35$ \\
\hline II & $\begin{array}{l}\text { N. cuniculi } \\
\text { N. ovis } \\
\text { N. caviae }\end{array}$ & $45.3-47.3$ & TND & TND & Very low & $\leq 42$ & 57.78 & $\leq 39$ \\
\hline III & B. catarrhalis & $41-42$ & Very low & Very low & High & 35 & $\leq 39$ & - \\
\hline
\end{tabular}

${ }^{a}$ Test not done.

${ }^{b}$ Percent binding.

${ }^{c}$ Data incomplete (see specific tables). Affiliation of $N$. cinerea, $N$. flavescens, and $N$. elongata with group I was based on genetic data previously reported $(4,6,8,16)$. 
restrictive about the DNA by which they are transformed than others. This is quite evident when $N$. lactamica and $N$. meningitidis are compared as recipients for donor DNA (Table $3)$. Although DNA from $N$. lactamica transformed $N$. meningitidis at high frequencies, it was not transformed by DNA from $N$. meningitidis reciprocally at a significant level. One might assume that this strain of $N$. lactamica is more restrictive in regard to discriminating against foreign DNA than is $N$. meningitidis. Although such differences in discrimination for foreign DNA occurring in various recipient cells may cause some difficulty in the interpretation of results, this study found that the differences need not preclude the use of transformation in taxonomy.

The determination of DNA hybridization among members of the aerobic gram-negative cocci by renaturation rate proved to be an effective, reproducible procedure. In general, the degrees of relatedness between aerobic gram-negative cocci revealed by this method corroborated those previously determined by the filter-membrane technique (17). Previous DNA hybridization results (17) indicated that the neisseriae can be divided into three main subgroups, as follows: (subgroup 1) $N$. meningitidis, and N. gonorrhoeae; (subgroup 2) $N$. perflava, N. subflava, N. sicca, N. flavescens, and N. flava; and (subgroup 3) B. catarrhalis and $N$. caviae. The results of our study did not indicate that $N$. caviae and $B$. catarrhalis exhibit sufficient DNA homology to be considered members of the same group. In addition, this study revealed greater homology between the DNAs of $N$. sicca and $N$. subflava (N. flava, $N$. subflava, and $N$. perflava) than previously reported.

Data from the DNA base composition, transformation, and DNA hybridization studies reported here suggest that the members of the genera Neisseria and Branhamella form three natural genetic groups (Table 7). These groups are separated by variations in DNA base composition, transformation barriers, and degree of DNA hybridization occurring within and between group members. Group I, comprised of $N$. meningitidis, $N$. gonorrhoeae, $N$. subflava, $N$. flava, N. perflava, N. sicca, N. mucosa, $N$. cinerea, $N$. flavescens, $N$. lactamica, and $N$. elongata, is characterized by the following: $\mathrm{G}+\mathrm{C}$ values of 49.3 to $54.7 \mathrm{~mol} \%$, significant levels of intergenic transformation occurring between members of this group but not with members of group 3, and high degrees of DNA hybridization (over $60 \%$ binding) with members of group 1 but significantly lower degrees of hybridization (less than $42 \%$ binding) with members of groups 2 and 3. Group 2, comprised of $N$. cuniculi, $N$. ovis and $N$. caviae, is characterized by the following: $\mathrm{G}+\mathrm{C}$ values of 45.3 to 47.3 mol\%, lack of significant transformation occurring with members of group 3 , and low degrees of DNA hybridization with members of groups 1 and 3 (less than $42 \%$ binding) but significant degrees between members of group $2(57.8 \%$ binding). Group 3, comprised of $B$. catarrhalis, is characterized by the following: $\mathrm{G}+\mathrm{C}$ values of 41 to $42 \mathrm{~mol} \% \mathrm{G}+\mathrm{C}$, lack of significant transformation with members of groups 1 and 2, and low degrees of DNA hybridization with members of groups 1 and 2 (less than 39\% binding). These data suggest that $N$. cuniculi, $N$. caviae, and $N$. ovis form a group sufficiently distinct from the other species of Neisseria and Branhamella to be considered for incorporation into a separate genus.

\section{ACKNOWLEDGMENTS}

We thank Thomas Maier for assistance with transformation studies and Ron Giard and Hsiao-Lai Liu for technical assistance.

We thank the Office of Naval Research and the Grossman Endowment Fund for financial support.

\section{LITERATURE CITED}

1. Bøvre, K. 1963. Affinities between Moraxella spp. and a strain of Neisseria catarrhalis as expressed by transformation. Brief report. Acta Pathol. Microbiol. Scand. 58:528.

2. Bøvre, K. 1967. Transformation and DNA base composition in taxonomy, with special reference to recent studies in Moraxella and Neisseria. Acta Pathol. Microbiol. Scand. 69:123-144.

3. Bøvre, K. 1970. Interspecies pulse-RNA-DNA hybridization in Moraxella and Neisseria, as compared with genetic transformation and DNA base determinations. Acta Pathol. Microbiol. Scand. Sect. A, B Suppl. 215:6-7.

4. Bøvre, K. 1970. Pulse RNA-DNA hybridization between rodshaped and coccal species of the Moraxella-Neisseria groups. Acta Pathol. Microbiol. Scand. Sect. B 78:565-574.

5. Bøvre, K., M. Fiandt, and W. Szybalski. 1969. DNA base composition of Neisseria, Moraxella, and Acinetobacter, as determined by measurement of buoyant density of $\mathrm{CsCl}$ gradients. Can. J. Microbiol. 15:335-338.

6. Bøvre, K., and E. Holten. 1970. Neisseria elongata sp. nov., a rod-shaped member of the genus Neisseria. Reevaluation of cell shape as a criterion in classification. $J$. Gen. Microbiol. 60:67-75.

7. Burton, K. 1968. Determination of DNA concentration with diphenyl-amine. Methods Enzymol. 12B:163-166.

8. Catlin, B. W., and L. S. Cunningham. 1961. Transforming activities and base contents of deoxyribonucleate preparations from various neisseriae. J. Gen. Microbiol. 26:303-312.

9. De Ley, J. 1970. Reexamination of the association between melting point, buoyant density, and chemical base composition of deoxyribonucleic acid. J. Bacteriol. 101:738-754.

10. De Ley, J., H. Cattoir, and A. Reynaerts. 1970. The quantitative measurement of DNA hybridization from renaturation rates. Eur. J. Biochem. 12:133-142.

11. De Ley, J., and R. Tijtgat. 1970. Evaluation of membrane filter methods for DNA-DNA hybridization. Antonie van Leeuwenhoek J. Microbiol. Serol. 36:461-474.

12. Frøholm, L. O., and K. Bøvre. 1973. The fimbriated state and competence in genetic transformation of three Morax- 
ella species, p. 125-139. In L. J. Archer (ed.), Bacterial transformation. Academic Press, Inc., New York.

13. Frøholm, L. O., K. Jyssum, and K. Bøvre. 1973. Electron microscopical and cultural features of Neisseria meningitidis competence variants. Acta Pathol. Microbiol. Scand Sect. B 81:525-537.

14. Holten, E. 1973. Glutamate dehydrogenases in genus Neisseria. Acta Pathol. Microbiol. Scand. Sect. B 81:49-58.

15. Holten, E. 1974. Immunological comparison of NADPdependent glutamate dehydrogenase and malate dehydrogenase in genus Neisseria. Acta Pathol. Microbiol. Scand Sect. B 82:849-859.

16. Jyssum, K., and S. Lie. 1965. Genetic factors determining competence in transformation of Neisseria meningitidis. 1. A permanent loss of competence. Acta Pathol. Microbiol. Scand. 63:306-316.

17. Kingsbury, D. T. 1967. Deoxyribonucleic acid homologies among species of the genus Neisseria. J. Bacteriol. 94:870-874.

18. LaMacchia, E. H., and M. J. Pelczar, Jr. 1966. Analyse of deoxyribonucleic acid of Neisseria caviae and other Neisseriae. J. Bacteriol. 91:514-516.

19. Lee, K. Y., R. Wahl, and E. Barbu. 1956. Contenu en bases puriques et pyrimidiques des acides deoxyribonucleiques des bacteries. Ann. Inst. Pasteur Paris 91:212-224.

20. Leidy, G., E. Hahn, and H. E. Alexander. 1956. On the specificity of deoxyribonucleic acid which induces streptomycin resistance in Hemophilus. J. Exp. Med. 104:305-320.

21. Leidy, G., E. Hahn, and H. E. Alexander. 1959. Interspecific transformation in Hemophilus; a possible index of relationship between $H$. influenzae and $H$. aegyptius. Proc. Soc. Exp. Biol. Med. 102:86-88.

22. Lowry, O. H., N. J. Rosebrough, A. L. Farr, and R. J. Randall. 1951. Protein measurement with the Folin phenol reagent. J. Biol. Chem. 193:265-275.

23. Maier, T. W., L. Zubrzycki, and M. B. Coyle. 1975. Genetic analysis of drug resistance in Neisseria gonorrhoeae; identification and linkage relationships of loci controlling drug resistance. Antimicrob. Agents Chemother. 7:676-681.

24. Mandel, M., and J. Marmur. 1968. Use of ultraviolet absorbance-temperature profile for determining the guanine plus cytosine content of DNA. Methods Enzymol. 12B:195-206.

25. Marmur, J. 1961. A procedure for the isolation of deoxyribonucleic acid from microorganisms. J. Mol. Biol. 3:208-218.

26. Marmur, J., and P. Doty. 1962. Determination of the base composition of deoxyribonucleic acid from its thermal denaturation temperature. J. Mol. Biol. 5:109-118.

27. Marmur, J., E. Seaman, and J. Levine. 1963. Interspecific transformation in Bacillus. J. Bacteriol. 85:461-467.

28. Pakula, R. 1962. Can transformation be used as a criterion in taxonomy of bacteria, p. 617-629. In N. E. Gibbons (ed.), Recent progress in microbiology, vol. 8. University of Toronto Press, Montreal.

29. Perry, D., and H. D. Slade. 1964. Intraspecific and interspecific transformation in streptococci. J. Bacteriol. 88:595-601.

30. Reyn, A. 1974. Family I. Neisseriaceae, p. 427-438. In R. E. Buchanan and N. E. Gibbons (ed.), Bergey's manual of determinative bacteriology, 8th ed. The Williams \& Wilkins Co., Baltimore.

31. Schildkraut, C. L., J. Marmur, and P. Doty. 1962. Determination of the base composition of deoxyribonucleic acid from its buoyant density in CsCl. J. Mol. Biol. 4:430-443.

32. Siddiqui, A., and I. D. Goldberg. 1975. Intergenic transformation of Neisseria gonorrhoeae and Neisseria perflava to streptomycin resistance and nutritional independence. J. Bacteriol. 124:1359-1365.

33. Skerman, V. B. D., V. McGowan, and P. H. A. Sneath (ed.). 1980. Approved lists of bacterial names. Int. J. Syst. Bacteriol. 30:225-420.

34. Snell, J. J. S., and S. P. Lapage. 1976. Transfer of some saccharolytic Moraxella species to Kingella Henriksen and B $\emptyset v r e 1976$, with descriptions of Kingella indologenes sp. nov. and Kingella denitrificans sp. nov. Int. J. Syst. Bacteriol. 26:451-458.

35. Sparling, P. F. 1966. Genetic transformation of Neisseria gonorrhoeae to streptomycin resistance. J. Bacteriol. 92:1364-1371.

36. White, L. A., and D. S. Kellogg, Jr. 1965. Neisseria gonorrhoeae identification in direct smears by a fluorescent antibody-counterstain method. Appl. Microbiol. 13:171-174. 